\title{
Isolation and Microbial Screening of 1-Methylcyclopentene from Bracystelma Togoense Schtlr
}

\author{
Abiche Ekalu ${ }^{*}$, Rachael Gbekele-Oluwa Ayo $^{2}$, James D Habila ${ }^{2}$ and Ibrahim Hamisu ${ }^{2}$ \\ ${ }^{1}$ Nigerian Army School of Education, Nigeria
}

${ }^{2}$ Ahmadu Bello University Zaria, Kaduna, Nigeria

Submission: May 09, 2019; Published: May 29, 2019

"Corresponding author: Abiche Ekalu, Nigerian Army School of Education, Ilorin, Kwara, Nigeria

\begin{abstract}
The secondary metabolites, 1-methylcyclopentene was isolated from the $\mathrm{CH}_{2} \mathrm{Cl}_{2}$ extract of Brachystelma togoense used traditionally for treatment of ailments. The structure was elucidated using 1H, 13C and 2D NMR. 1-methylcyclopentene previously undescribed from plant sources had shown various biological activities S. aureus, E. coli, S. pneumonia, S. typhi, and C. albicans. It was observed that 1-methylcyclopentene was more active against $C$. albicans $(24 \mathrm{~mm})$ and E. coli $(20 \mathrm{~mm})$. 1-methylcyclopentene also showed the highest activity against $E$. coli $(0.1875$ $\mathrm{mg} / \mathrm{mL})$ and C. albicans $(0.1875 \mathrm{mg} / \mathrm{mL})$. The $\mathrm{MBC} / \mathrm{MFC}$ was observed for E. coli $(0.75 \mathrm{mg} / \mathrm{mL})$, S. pneumonia $(0.75 \mathrm{mg} / \mathrm{mL})$, S. typhi $(0.75 \mathrm{mg} /$ $\mathrm{mL})$ and C. albicans $(0.375 \mathrm{mg} / \mathrm{mL})$ respectively. The activity of 1-methylcyclopentene in B. togoense justified ethnomedicinal uses of the plant.

Keywords: Phyto Chemical; 1-methylcyclopentene; Brachystelma togoense Schtlr
\end{abstract}

\section{Introduction}

Medicinal plants are used in developing countries as alternative medical treatments and extracts and essential oils isolated from these plants have shown biological activity in vitro and in vivo [1]. Mankind has explored herbal medicines for relieving pain and to cure various diseases for the last 60,000 years [2]. Nowadays, more than $50 \%$ of natural drugs being used for medication, are of plant origin [2,3]. According to the World Health Organization (WHO), about $80 \%$ of the world's population use herbs and other traditional medicines for their primary healthcare and three kinds of herbal medicines are used: raw plant materials, processed plant materials and herbal products [4]. Herbal medicines are natural products that have proved to be safe, both due to their low side-effects while being used to treat diseases and also acting at the same time as dietary supplements preventing the human body from such diseases. Many of the Tuberous Brachystelma are known to be used medicinally for the treatment of headache, stomachache and colds in children. In China, Brachystelma edule tubers are edible and the plant is used for the treatment of coughs and reduction of phlegm [5].

\section{Materials and Method}

\section{Collection of Plant}

The stem bark of brachystelma togoense was collected in April 2018 from Benue State, Nigeria. The plant was identified by the plant taxonomist Mallam Sanusi Namadi and a voucher specimen (no. 25856) is retained in Biological Science Depatment, Ahmadu Bello University, Zaria-Nigeria.

\section{Extraction and Isolation}

The air-dried B. togoense was manually reduced to powder using mortar and pestil. Exactly $1000 \mathrm{~g}$ of the powdered plant material was extracted on a shaker at room temperature using $100 \%$ dichloromethane $\left(\mathrm{CH}_{2} \mathrm{Cl}_{2}\right)$ for $72 \mathrm{~h}$. The extracts were concentrated using a rotary evaporator at $40^{\circ} \mathrm{C}$ resulting in a brown gum-like texture $(32 \mathrm{~g})$. The $\mathrm{CH}_{2} \mathrm{Cl}_{2}$ extract was separated by flash chromatography (Biotage SP1) over silica gel using three solvents. Firstly, a hexane/ $\mathrm{CH}_{2} \mathrm{Cl}_{2}$, gradient starting with $100 \%$ hexane and gradually increasing the polarity to $100 \% \mathrm{CH}_{2} \mathrm{Cl}_{2}$. Secondly, $\mathrm{CH}_{2} \mathrm{Cl}_{2} / \mathrm{EtOH} / \mathrm{Ac}$ from a $100 \% \mathrm{CH}_{2} \mathrm{Cl}_{2}$ to $50 \% \mathrm{EtOH} / \mathrm{Ac}$ and to $100 \% \mathrm{EtOH} /$ Ac to yield various fractions (fr. 1-100). Fr.5 was spotted on the TLC plate using $100 \% \mathrm{CH}_{2} \mathrm{Cl}_{2}$ and appeared a pure compound 1 (70.0mg).

\section{Structural Elucidation of Compound}

Compound 1 was isolated as a cream solid from the $\mathrm{CH}_{2} \mathrm{Cl}_{2}$ extract of the aerial parts of Brachystelma togoense and identified as the 1-methylcyclopentene, which is being reported for the first time from plant source. However, 1-methylcyclopentene has been reported from the $\mathrm{CH}_{2} \mathrm{Cl}_{2}$ extract 
of Iridomyrmex discors (ants) (6). The IR spectrum (spectrum 1-4) showed absorbance bands for aliphatic methylene (3054 and $1422 \mathrm{~cm}^{-1}$ ) and sp3 $\mathrm{CH}$ (2987 and $1375 \mathrm{~cm}^{-1}$ ) groups. The 13C NMR spectrum (spectrum 3) showed six resonances including two alkene carbon resonances at $\delta_{\mathrm{C}} 135.1$ (C-1) and $124.4 \mathrm{C}-2)$. The three carbon resonances $\left(\delta_{C} 40.0, \delta C 29.9\right.$, $\left.\delta_{C} 26.9\right)$ and a vinyl methyl group resonance $\left(\delta_{C} 16.3\right)$ whose corresponding methyl group proton resonance occurred at $\delta \mathrm{H}$ 1.53s). The COSY spectrum (spectrum 5-7) showed correlations between the $\mathrm{H}-2$ and two $\mathrm{H}-3$ resonances and also long-range coupling with the $3 \mathrm{H}-6$ resonances. Coupling was seen between methylene protons. This compound has been isolated before [6] but not from plants. The $1 \mathrm{H}$ and $13 \mathrm{C}$ NMR resonances were assigned using HSQC and HMBC spectra and are given in Table 1 the structure of compound 1 is shown in (Figure 1).

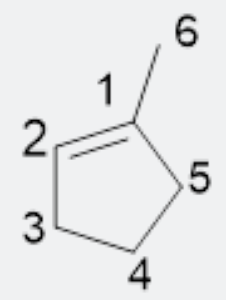

Figure 1: 1-methylcyclopentene.

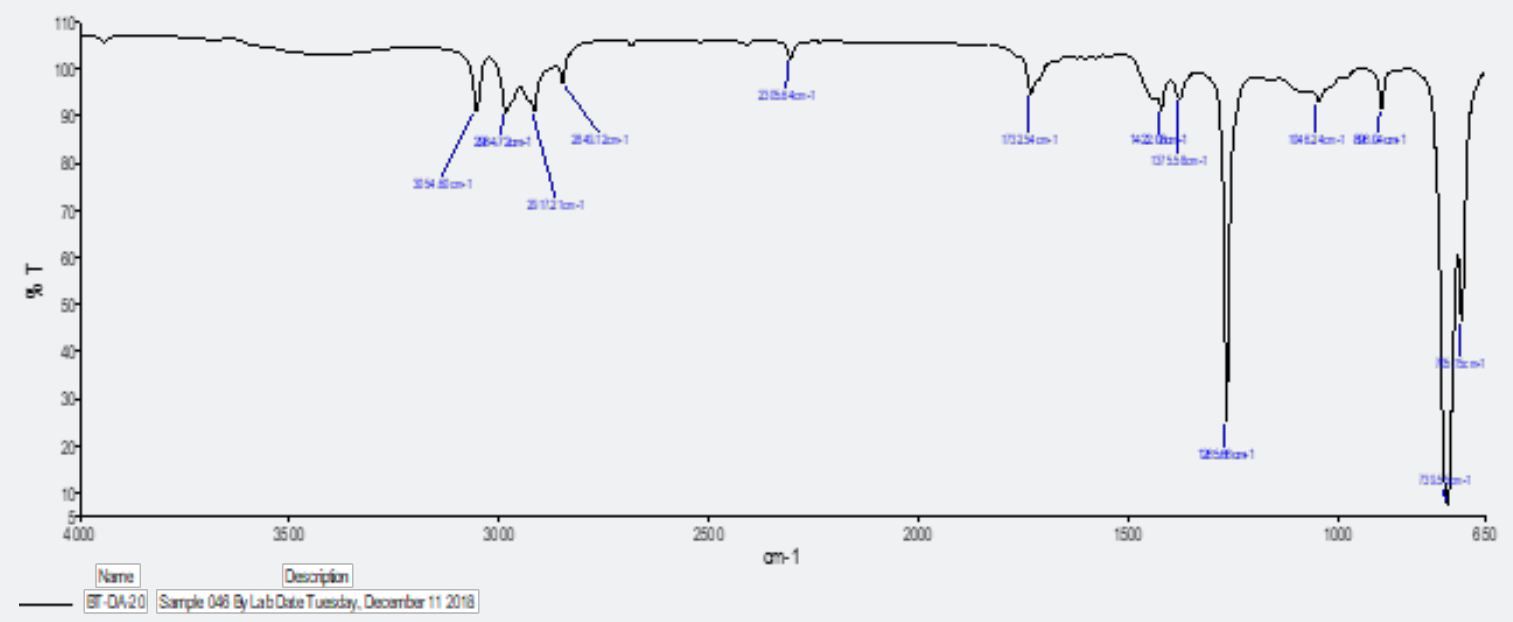

Spectrum 1: FTIR spectrum for compound 1.

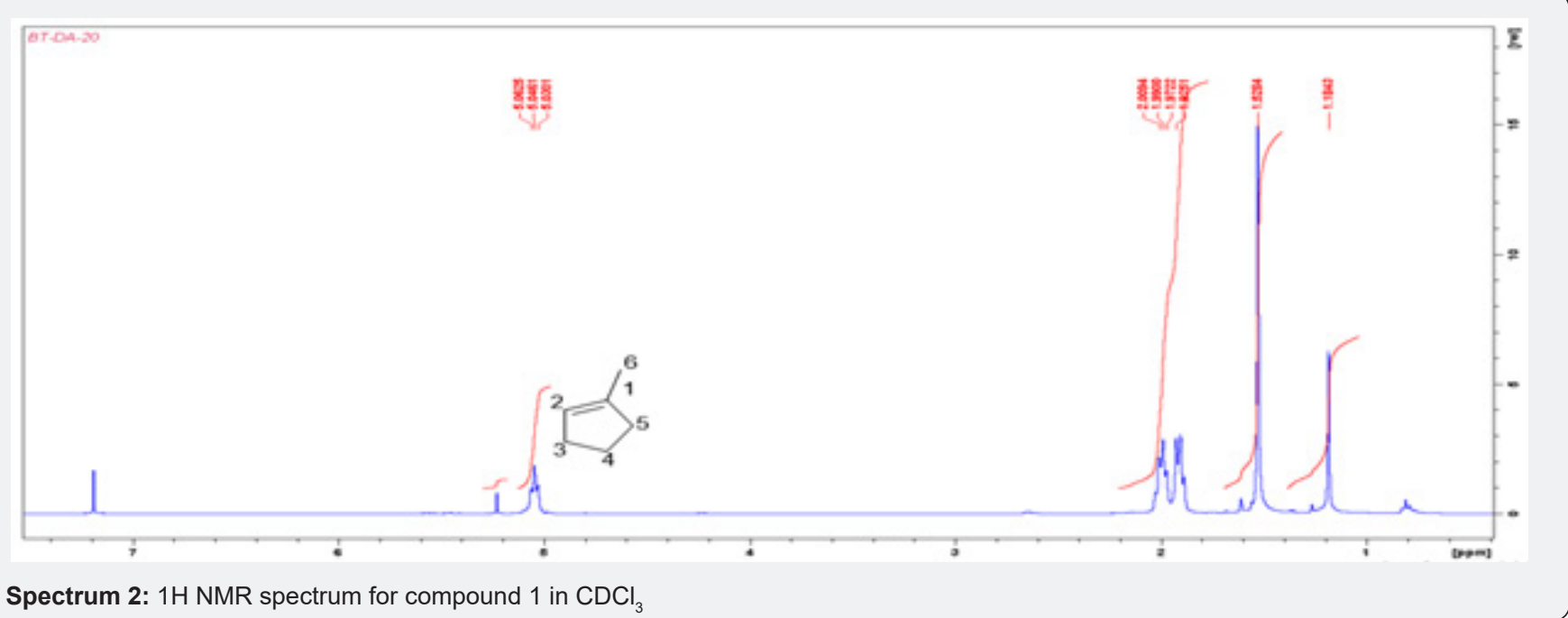

Table 1: Correlation table for 1-methylcyclopentene.

\begin{tabular}{|c|c|c|c|c|c|c|}
\hline C & $\begin{array}{c}{ }^{13} \mathrm{C} \mathrm{NMR(100MHz)} \text { in } \\
\text { CDCl }_{3}\end{array}$ & $\begin{array}{c}\left.{ }^{1} \mathrm{H} \mathrm{NMR(500MHz}\right) \text { in } \\
\operatorname{CDCl}_{3}(6)\end{array}$ & $\begin{array}{c}{ }^{1} \mathrm{H} \text { NMR }(400 \mathrm{MHz}) \mathrm{CDCl}_{3} \\
\text { ( } \mathrm{J} \text { in } \mathrm{Hz})\end{array}$ & HMBC $(\mathrm{H} \rightarrow \mathrm{C})$ & $\operatorname{cosY}$ & NOESY \\
\hline 1 & $135.1 \mathrm{C}$ & & - & & & \\
\hline 2 & $124.5 \mathrm{CH}$ & $5.3(1 \mathrm{H}, \mathrm{m})$ & $5.05 \mathrm{t}, \mathrm{J}=6.7$ & $1,3,4,5,6$ & $3 \alpha, 5 \alpha$ & $3 \alpha, 4 \alpha$ \\
\hline 3 & $29.9 \mathrm{CH}_{2}$ & & 1.08 br W $1 / 2=2.7$ & $1,2,4,5$ & & \\
\hline 4 & $26.9 \mathrm{CH}_{2}$ & $2.2-2.3(6 \mathrm{H}, \mathrm{m})$ & $1.99 \mathrm{dd}, \mathrm{J}=7.4,14.8$ & $1,2,3,5$ & & \\
\hline
\end{tabular}


Organic and Medicinal Chemistry International Journal

\begin{tabular}{|c|c|c|c|c|c|}
\hline & & & $1.91 \mathrm{t}, \mathrm{J}=8.8$ & & \\
\hline 5 & $40.0 \mathrm{CH}_{2}$ & & $1.99 \mathrm{dd}, \mathrm{J}=7.4,14.8$ & $1,2,3,4,6$ & \\
\hline & & & $1.91 \mathrm{t}, \mathrm{J}=8.8$ & & \\
\hline 6 & $16.3 \mathrm{CH}_{3}$ & $1.7(3 \mathrm{H} \mathrm{brs})$ & $1.53 \mathrm{~s}$ & $1,2,5$ & \\
\hline
\end{tabular}

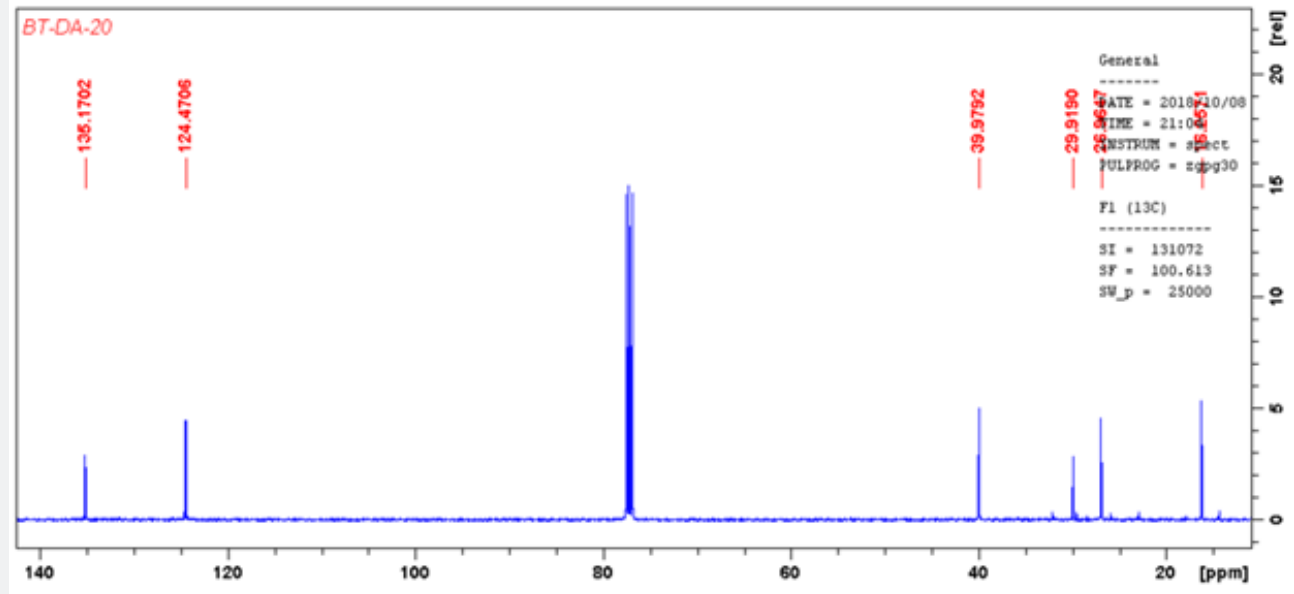

Spectrum 3: $13 \mathrm{C}$ NMR spectrum for compound 1 in $\mathrm{CDCl}_{3}$.

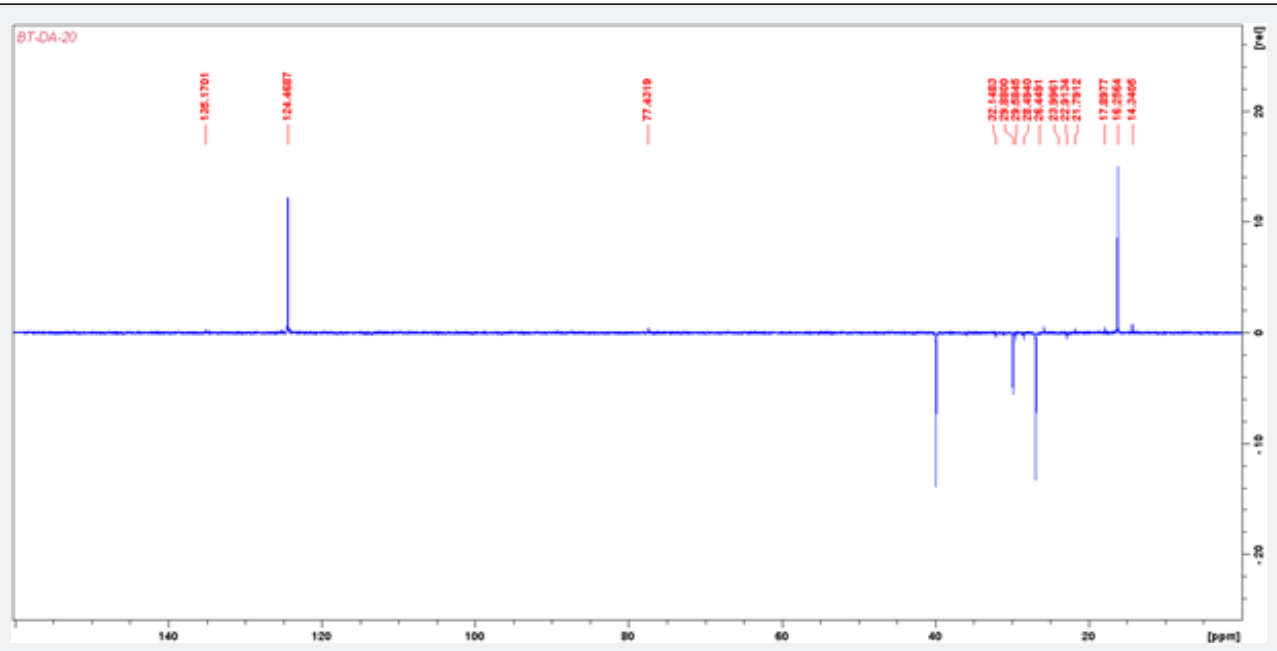

Spectrum 4: DEPT spectrum for compound 1 in $\mathrm{CDCl}_{3}$.

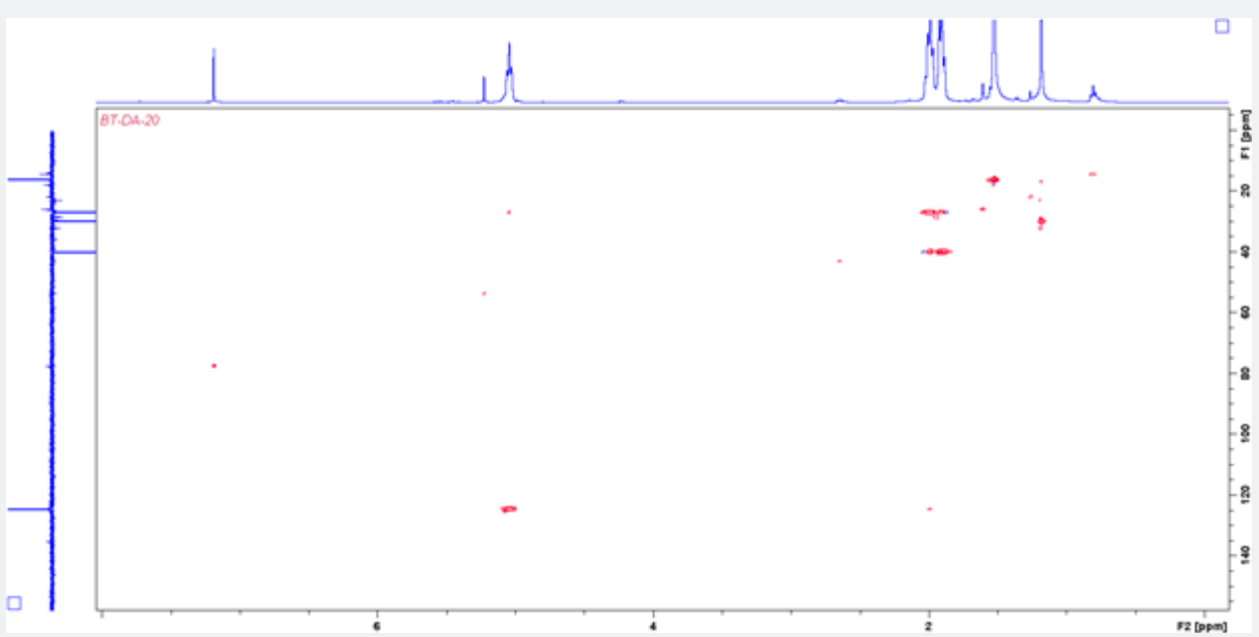

Spectrum 5: HSQCDEPT spectrum for compound 1 in $\mathrm{CDCl}_{3}$. 


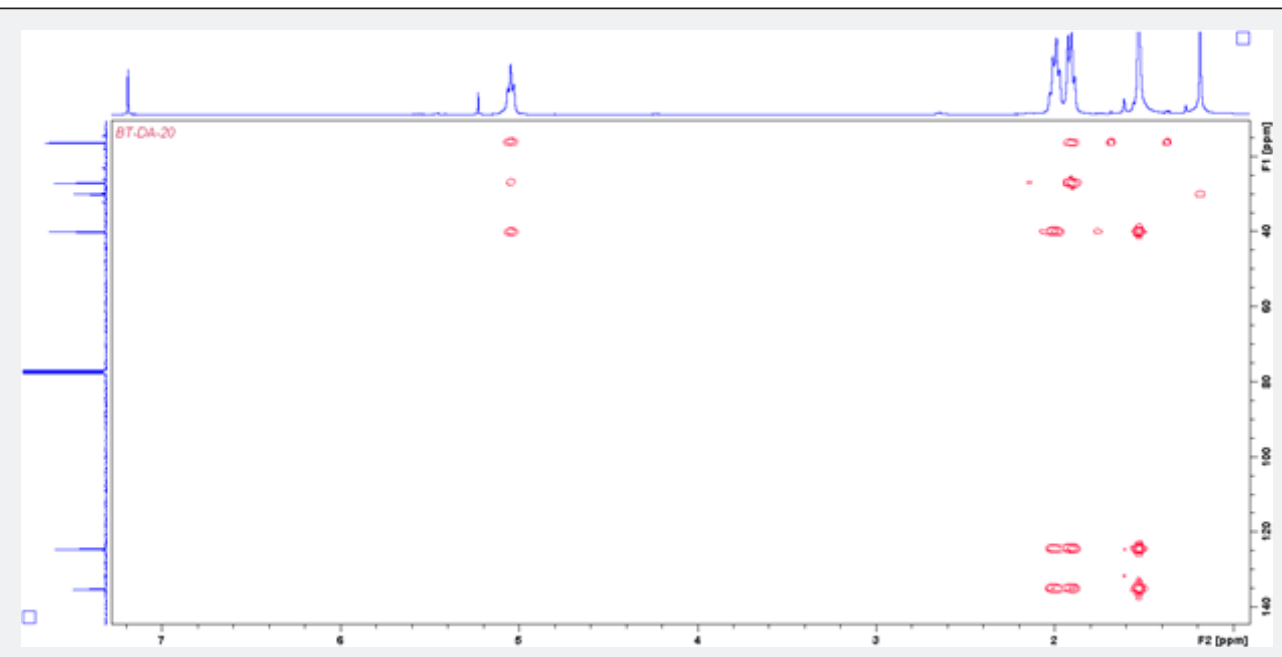

Spectrum 6: HMBC spectrum for compound 1 in $\mathrm{CDCl}_{3}$.

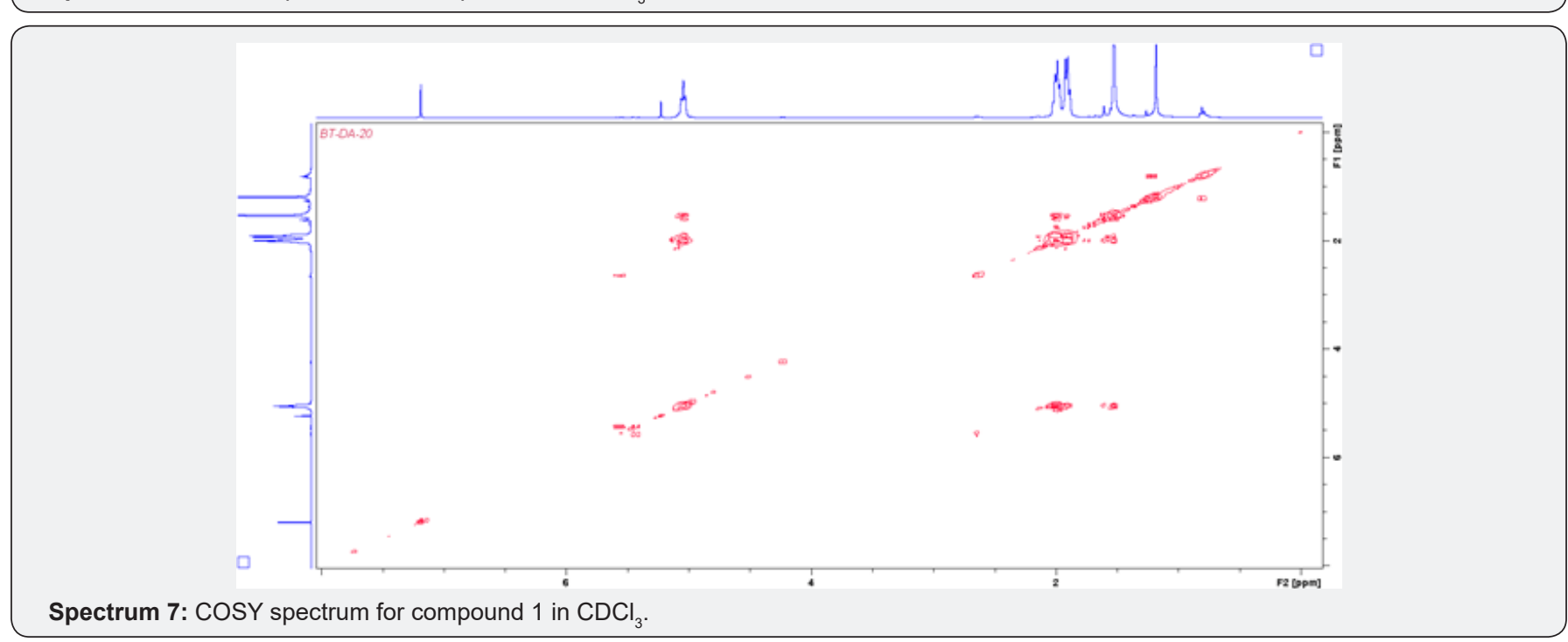

\section{Test Organism}

The microorganisms tested were: Staphylococcus aureus, Streptococcus pneumoniae, Escherichia coli, Salmonella typhi, and Candida albicans. They were obtained from the Department of Medical Microbiology, Ahmadu Bello University Teaching Hospital (ABUTH), Shika, Zaria. All the isolates were checked for purity and maintained in nutrient agar slant (Figure 2).

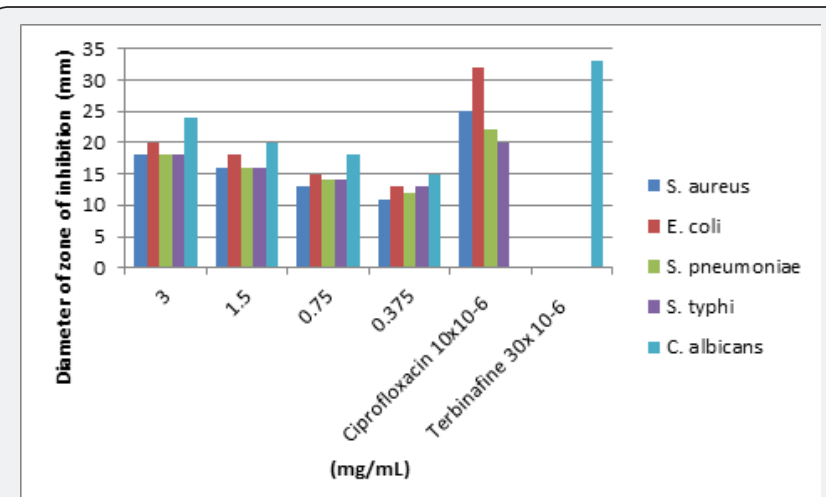

Figure 2: Diameter of Zone of Inhibition (mm).

\section{Determination of Zone of Inhibition}

The standardized inocula of the isolates were uniformly streaked unto freshly prepared Mueller Hinton agar plates with the aid of a sterile swab stick. Using a sterile cork borer $(6 \mathrm{~mm}$ in diameter), 5 appropriately labeled wells were punched into each agar plate. Aliquot of $0.3 \mathrm{~mL}$ of the appropriate isolate concentration was placed in each well and then allowed to diffuse into the agar. An extra plate was streaked with the isolate and ciprofloxacin $(10 \mu /$ disc $)$ was placed on it. The plates were incubated at $37^{\circ} \mathrm{C}$ for $24 \mathrm{~h}$. While for the fungi, Sabouraud dextrose broth was used and the incubation period was $30^{\circ} \mathrm{C}$ and $48 \mathrm{~h}$. The antimicrobial activities were expressed as diameter $(\mathrm{mm})$ of inhibition zones produced by the plant extracts spectrum 8 .

\section{Determination of Minimum Inhibition Concentration (MIC)}

The minimum inhibition concentrations of the isolates were carried out on the test microbes using the broth dilution method as outlined by the Clinical and Laboratory Standards Institute [7]. Mueller Hinton broth was prepared; $10 \mathrm{~mL}$ was dispensed 
into tubes and was sterilized at $121^{\circ} \mathrm{C}$ for 15 minutes and allowed to cool. The McFarland turbidity standard scale 0.5 was prepared to give turbidity solution. Normal saline was prepared, $10 \mathrm{~mL}$ was dispensed into sterile test tube and the test microbes was inoculated and incubated at $37^{\circ} \mathrm{C}$ for 24 hours. Dilution of the test microbes was done in the normal saline until the turbidity marched that of the Mc-Farland turbidity scale by visual comparison at this point the test microbe has a concentration of about $1.5 \times 108 \mathrm{cfu} / \mathrm{mL}$. Two-fold serial dilution of the extracts in the sterilized broth was made to obtain the concentrations of 3 $\mathrm{mg} / \mathrm{mL}, 1.5 \mathrm{mg} / \mathrm{mL}, 0.75 \mathrm{mg} / \mathrm{mL}, 0.375 \mathrm{mg} / \mathrm{mL}, 0.1875 \mathrm{mg} / \mathrm{mL}$ and $0.09375 \mathrm{mg} / \mathrm{mL}$. The initial concentration was obtained by dissolving $6 \mathrm{mg}$ of the isolate in $10 \mathrm{~mL}$ of the sterile broth. Having obtained the different concentrations of the extracts in the sterile broth, $0.3 \mathrm{~mL}$ of the standard inoculum of the test microbe in the normal saline was then inoculated into the different concentrations. Incubation was made at $37{ }^{\circ} \mathrm{C}$ for $24 \mathrm{~h}$, after which each test tube of the broth was observed for turbidity (growth). The lowest concentration of the extract in which the broth shows no turbidity was recorded as the Minimum Inhibition Concentration (MIC).

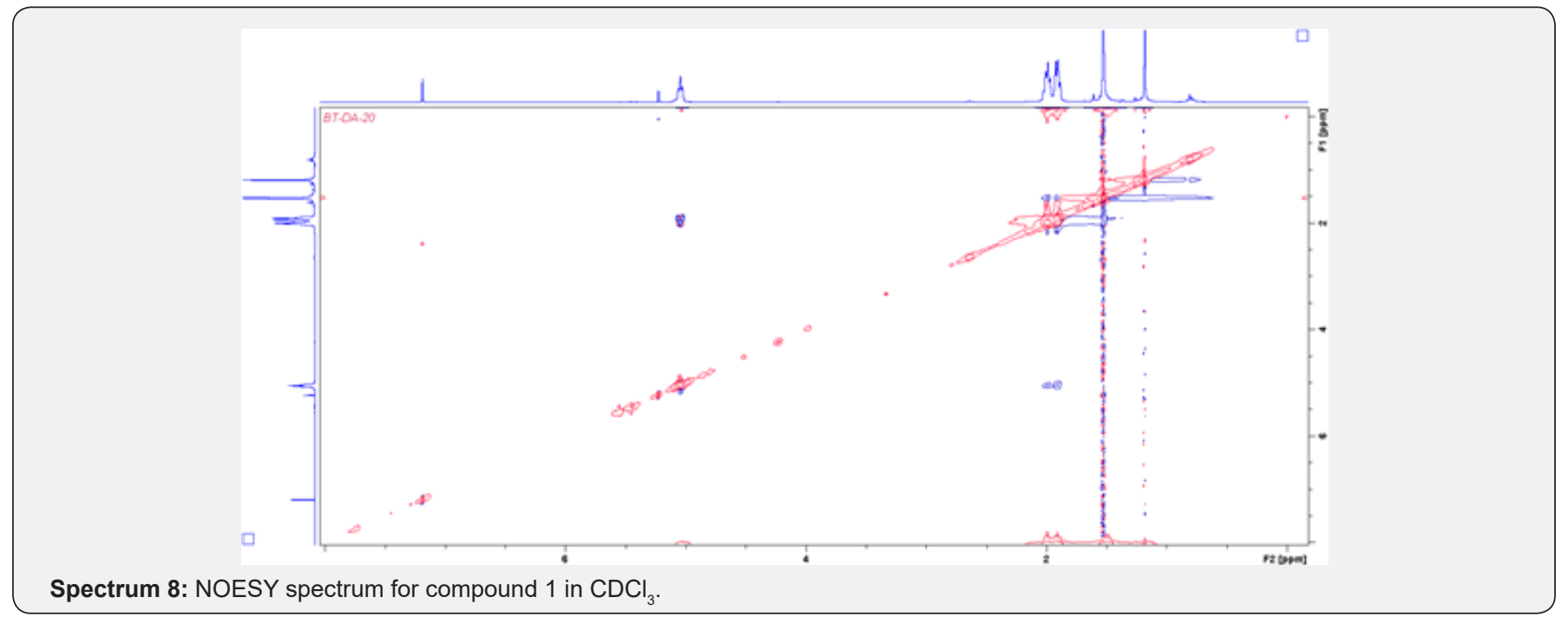

Determination of Minimum Bactericidal Concentration/ Minimum Fungicidal Concentration (MBC/MFC)

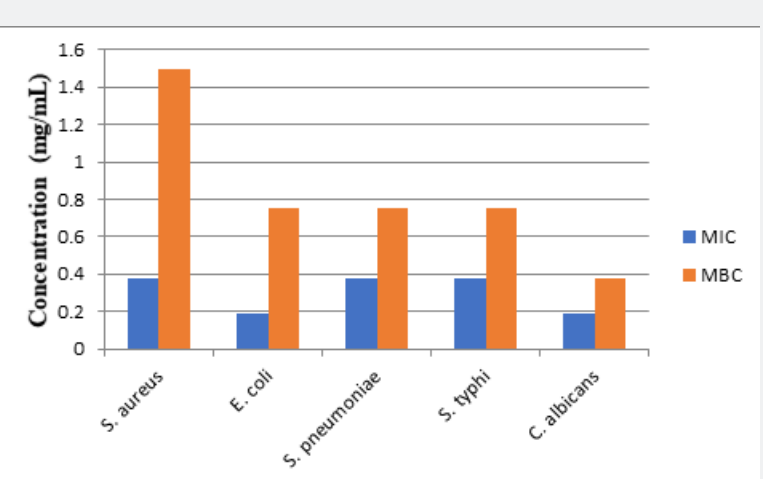

Figure 3: Minimum Inhibition Concentration (MIC), Minimum Bactericidal Concentration (MBC) and Minimum Fungicidal Concentration (MFC).

The minimum bactericidal concentration of the extracts was determined as outlined by the CLSI on the nutrient agar plates. Minimum bactericidal concentrations were determined by assaying the test tube contents of the MIC determinations. A loopful of the content of each tube was inoculated by streaking on a solidified nutrient agar plate and then incubated at $37^{\circ} \mathrm{C}$ for $24 \mathrm{~h}$ for bacterial and $30^{\circ} \mathrm{C}$ for $48 \mathrm{~h}$ for fungi. After which it was observed for microbial growth. The lowest concentration of the subculture with no growth was considered as minimum bactericidal concentration/ minimum fungicidal concentration (Figure 3).

\section{Conclusion}

The secondary metabolites, 1-methylcyclopentene was isolated from the $\mathrm{CH}_{2} \mathrm{Cl}_{2}$ extract of Brachystelma togoense used traditionally for treatment of ailments. The structure was elucidated using ${ }^{1} \mathrm{H},{ }^{13} \mathrm{C}$ and 2D NMR. 1-methylcyclopentene previously undescribed from plant sources had shown various biological activities S. aureus, E. coli, S. pneumonia, S. typhi, and C. albicans. It was observed that 1-methylcyclopentene was more active against C. albicans $(24 \mathrm{~mm})$ and E. coli $(20 \mathrm{~mm})$. 1-methylcyclopentene also showed the highest activity against $E$. coli $(0.1875$ $\mathrm{mg} / \mathrm{mL})$ and C. albicans $(0.1875 \mathrm{mg} / \mathrm{mL})$. The MBC/MFC was observed for E. coli $(0.75 \mathrm{mg} / \mathrm{mL})$, S. pneumonia $(0.75 \mathrm{mg} / \mathrm{mL}), S$. typhi $(0.75 \mathrm{mg} / \mathrm{mL})$ and C. albicans $(0.375 \mathrm{mg} / \mathrm{mL})$ respectively. The activity of 1-methylcyclopentene in B. togoense justified ethnomedicinal uses of the plant.

\section{Acknowledgment}

The wishes to thanks the Natural products Research Group, University of Surrey, UK for the bench work opportunity.

\section{References}

1. Höfling J, Anibal PC, Obando-Pereda G, A T Peixoto I, Furletti VF, et al. (2010) Antimicrobial potential of some plant extracts against Candida species. Braz J Biol70(4): 1065-1068. 
2. Fabricant DS, Farnsworth NR (2001) The value of plants used in traditional medicine for drug discovery. Environ Health Perspect 109 (Suppl 1): 69-75.

3. Yarnell E, Abascal K (2002) Overview of Drug-Herb Interactions. Alternative and Complementary Therapies. Alternative and Complementary Therapies: Alternative and Complementary Therapies 8: 87-96.

4. Samoisy AK, Mahomoodally MF (2015) Ethnopharmacological analysis of medicinal plants used against non-communicable diseases in Rodrigues Island, Indian Ocean. J Ethnopharmacol 173: 20-38.
5. Prasad K, Prasanna P V, Meve U, Rao MS, Thulasaiah T (2016) Brachystelma annamacharyae sp. nov. (Apocynaceae) from the Seshachalam hills of Andhra Pradesh (India). Nordic Journal of Botany 34(3):360-363.

6. Cox MF, Brophy JJ, Toia RF (1989) Chemotaxonomy of the australian dolichoderinae: Volatile constituents of Iridomyrmex discors. Journal of Natural Products 52(1): 75-80.

7. Clinical and Laboratory Standards Institute (CLSI) (2017). Performing Standards for Antimicrobial Susceptibility Testing 32: 27.

\section{Your next submission with Juniper Publishers will reach you the below assets}

- Quality Editorial service

- Swift Peer Review

- Reprints availability

- E-prints Service

- Manuscript Podcast for convenient understanding

- Global attainment for your research

- Manuscript accessibility in different formats

( Pdf, E-pub, Full Text, Audio)

- Unceasing customer service

Track the below URL for one-step submission https://juniperpublishers.com/online-submission.php 